\title{
Measurements of temperature and heat of phase transformation of pure silicon by using differential scanning calorimetry
}

\author{
Marta Homa ${ }^{1}$ (D) Natalia Sobczak ${ }^{1,2}$
}

Received: 3 December 2018/Accepted: 16 August 2019/Published online: 3 September 2019

(C) The Author(s) 2019

\begin{abstract}
Differential scanning calorimetry (DSC) technique has been applied for the experimental determination of temperature and heat of phase transition of pure silicon $(7 \mathrm{~N})$ during heating and cooling cycles at the rate of $10 \mathrm{~K}$ min ${ }^{-1}$. The measurements were carried out in the temperature range of $25-1450{ }^{\circ} \mathrm{C}$ in a flow gas atmosphere (Ar, 99.9992\%) using three types of crucibles made of alumina, h-BN and alumina covered with h-BN coating. The following characteristics were estimated from DSC curves: melting point of silicon- $1414{ }^{\circ} \mathrm{C}$, the heat of fusion- $1826 \mathrm{~J} \mathrm{~g}{ }^{-1}$ and the heat of solidification- $1654 \mathrm{~J} \mathrm{~g}^{-1}$. It was found that the silicon evaporation phenomenon accompanying the tests had no effect on the measurements of temperature during solid-to-liquid and liquid-to-solid transformations and on the measurement of the latent heat of fusion. The effect of crucible type on the DSC measurements is discussed.
\end{abstract}

Keywords Silicon · Boron nitride $\cdot$ Alumina $\cdot$ h-BN coating $\cdot$ DSC $\cdot$ Latent heat of fusion · Latent heat of crystallization

\section{Introduction}

The continuous increase in thermal energy consumption in the world causes intensification of research on its acquisition and storage owing to the use of thermal energy storage (TES) systems [1]. Among different possible solutions for TES systems, those based on latent heat storage of phase change materials (PCMs) are the most efficient since they provide much higher storage density with a smaller temperature difference between storing and releasing heat [2].

Recently, $\mathrm{Si}$ and $\mathrm{Si}-\mathrm{B}$ alloys have been recognized as promising high-temperature PCM candidates taking into account their theoretically high latent heat of fusion values (e.g., $1800 \mathrm{~J} \mathrm{~g}^{-1}$ and $4650 \mathrm{~J} \mathrm{~g}^{-1}$ for $\mathrm{Si}$ and $\mathrm{B}$, respectively) [3]. Therefore, reliable information on the latent heat of fusion $\mathrm{Si}-\mathrm{B}$ alloys is of a great practical importance. In the open literature, there are no data for $\mathrm{Si}-\mathrm{B}$ or

Marta Homa

marta.homa@iod.krakow.pl

1 Foundry Research Institute, 73 Zakopiańska Str., 30-418 Kraków, Poland

2 Institute of Precision Mechanics, 3 Duchnicka Str., 01-796 Warsaw, Poland
Si-B-based alloys while only a few data are available for pure $\mathrm{Si}$ and $\mathrm{B}$. For pure $\mathrm{Si}$, experimental values of melting temperature and latent heat of fusion are reported in [4-13] and they are scattered and even contradicted. Their analysis suggests that the values the latent heat of fusion $\left(1851 \mathrm{~J} \mathrm{~g}^{-1}\right)$ and melting temperature $\left(1414{ }^{\circ} \mathrm{C}\right)$ reported by Yamaguchi et al. [4] are the most reliable. They were experimentally determined by a drop calorimetry method using a sealed hexagonal boron nitride (h-BN) container in the temperature range of $427-1547{ }^{\circ} \mathrm{C}$. However, in the study [4], the value of the latent heat of solidification of pure Si was not specified. For pure boron, situation is more complicated because only theoretical values of thermophysical properties are reported in the literature.

This work was performed in a frame of AMADEUS project [3], and it discusses the results of differential scanning calorimetry measurements (DSC) of the critical temperatures of pure $\mathrm{Si}$ and latent heat of fusion/latent heat of crystallization in the temperature range from 25 to $1450{ }^{\circ} \mathrm{C}$ under flowing $\mathrm{Ar}$ using a commercial thermal microbalance Netzsch STA 449 F3 Jupiter ${ }^{\circledR}$ and commercial crucibles made from boron nitride and alumina. 


\section{Experimental}

The following materials were used in this work:

(1) Ultrahigh purity silicon $(7 \mathrm{~N})$-the selected silicon material was amorphous polysilicon produced by the commercial Siemens process, in which $\mathrm{Si}$ is precipitated from high-purity silane $\left(\mathrm{SiH}_{4}\right)$ or trichlorosilane $\left(\mathrm{HSiCl}_{3}\right)$ gases at elevated temperatures;

(2) Commercially available hexagonal boron nitride (h$\mathrm{BN})$;

(3) Alumina $\left(\mathrm{Al}_{2} \mathrm{O}_{3}\right)$ Netzsch crucibles;

(4) Commercially available h-BN spray Henze HeBoCoat $^{\circledR}$ 401E (ceramic slurry) for alumina.

DSC measurements were carried out using a commercial thermal microbalance Netzsch STA 449 F3 Jupiter ${ }^{\circledR}$ device equipped with Pt-Rh DSC-C $\mathrm{C}_{\mathrm{p}}$ sample holder. Estimation of critical temperatures and latent heat of fusion/latent heat of crystallization was done with a Netzsch Proteus Thermal Analysis 6.1.0 software. DSC tests were performed in the temperature range from 25 to $1450{ }^{\circ} \mathrm{C}$ under flowing argon with a heating/cooling rate of $10 \mathrm{~K} \mathrm{~min}^{-1}$. The tests were carried out in protective atmosphere (Ar) in order to suppress $\mathrm{Si}$ vaporization because in vacuum, $\mathrm{Si}$ already evaporates at a temperature of $1337^{\circ} \mathrm{C}$ [14], i.e., below melting point of $\mathrm{Si}$.

For the selected temperature range, sensitivity and temperature calibrations were made with five pure metals (In, Bi, $\mathrm{Al}, \mathrm{Au}, \mathrm{Ni}$ ) using commercial $\mathrm{Al}_{2} \mathrm{O}_{3}$ crucibles (Netzsch) and the same other conditions as those applied for investigation of pure Si (flowing Ar; heating/cooling rate of $10 \mathrm{~K} \mathrm{~min}^{-1}$ ).

After the DSC tests, the crucibles were removed from the DSC holder and then subjected to structural evaluations by using scanning electron microscope (Hitachi 3000) and nondestructive analysis by 3D-computed tomography imaging (Nanotom 180). CT examinations were performed with the following exposure parameters: voltage- $90 \mathrm{kV}$, current $-170 \mu \mathrm{A}$ and voxel size- $4.0 \mu \mathrm{m} \mathrm{vox}^{-1}$. Computer processing and data analysis were carried out in a specialized datos/x-reconstruction using VGStudio Max 2.0 software.

\section{Results and discussion}

\section{DSC test with h-BN crucible (Test \#1)}

The first DSC test was performed with h-BN crucibles, i.e., both sample crucible and reference crucible were made from h-BN. The selection of h-BN crucibles was based on the findings of the detailed study on the interaction between molten $\mathrm{Si}$ and h-BN recently reported by Polkowski et al. [15] who evidenced negligible reactivity of the $\mathrm{Si} / \mathrm{h}-\mathrm{BN}$ system in the temperature range of our interest. Commercial h-BN crucibles of NGB808836 type ( $85 \mu \mathrm{l})$ [16] produced by Netzch were used in this study.

The silicon sample was cut into small piece $(30.43 \mathrm{mg})$, cleaned with acetone and placed in the middle of the h-BN sample crucible. After placing the sample crucible and reference crucible in a thermal microbalance chamber, the test system was rinsed with argon of $99.9992 \%$ purity for $30 \mathrm{~min}$ at $25^{\circ} \mathrm{C}$ and then the DSC test was started. It should be highlighted that the Proteus Analysis 6.1 software used in this study does not take into consideration the selection of h-BN crucibles. Therefore, according to the recommendations by the producer of DSC device, the calibration was made for $\mathrm{Al}_{2} \mathrm{O}_{3}$ crucibles.

The runs of DSC curves plotted upon heating and cooling of $\mathrm{Si}$ sample in h-BN crucible are presented in Fig. 1a and b, respectively. There is one endothermic effect on the DSC curve recorded during Si melting (Fig. 1a). After reaching the temperature of $1418{ }^{\circ} \mathrm{C}$, the Si sample starts melting while the maximum peak is at $1434{ }^{\circ} \mathrm{C}$. The calculated latent heat of fusion is $1114 \mathrm{~J} \mathrm{~g}^{-1}$. During cooling, one exothermic peak is visible (Fig. 1b). The solidification of liquid Si starts at $1399{ }^{\circ} \mathrm{C}$ and exothermic peak reaches its maximum at $1387^{\circ} \mathrm{C}$ while the calculated latent heat of solidification is $1002 \mathrm{~J} \mathrm{~g}^{-1}$.

To perform visual examinations of the solidified $\mathrm{Si}$ sample, an attempt was made to open the crucible. Unfortunately, it failed and the lid could not be removed. Therefore, in the next step, nondestructive analysis by 3Dcomputed tomography (CT) imaging [17] was used to see the crucible interior. Figure $2 \mathrm{a}$ depicts the representative 3D-CT image of the h-BN crucible with solidified $\mathrm{Si}$ sample inside, while 2D-CT image of cross section of the crucible wall is shown in Fig. 2b. The CT analysis evidenced that the solidified Si sample did not contact the lid, and its one side was on the crucible bottom though another side was connected with the crucible wall (Fig. 2a). The crucible wall was porous (Fig. 2b), and occasionally it contained some light precipitates.

The more detailed CT analysis of the crucible lid showed its connection with one crucible wall (Fig. 3a), and the presence of some light precipitates inside connection and lid hole (Fig. 3b).

Moreover, numerous pores in the crucible wall were detected that might be responsible for weak mechanical resistance of h-BN crucible and its failure in the next attempt to separate the lid from the crucible. In this attempt, the crucible fell into pieces under the effect of a small mechanical force. The Si sample extracted from the crushed crucible was weighed on an analytical balance, and a mass loss of $\Delta m=5.8 \%$ was recorded. Most probably, 

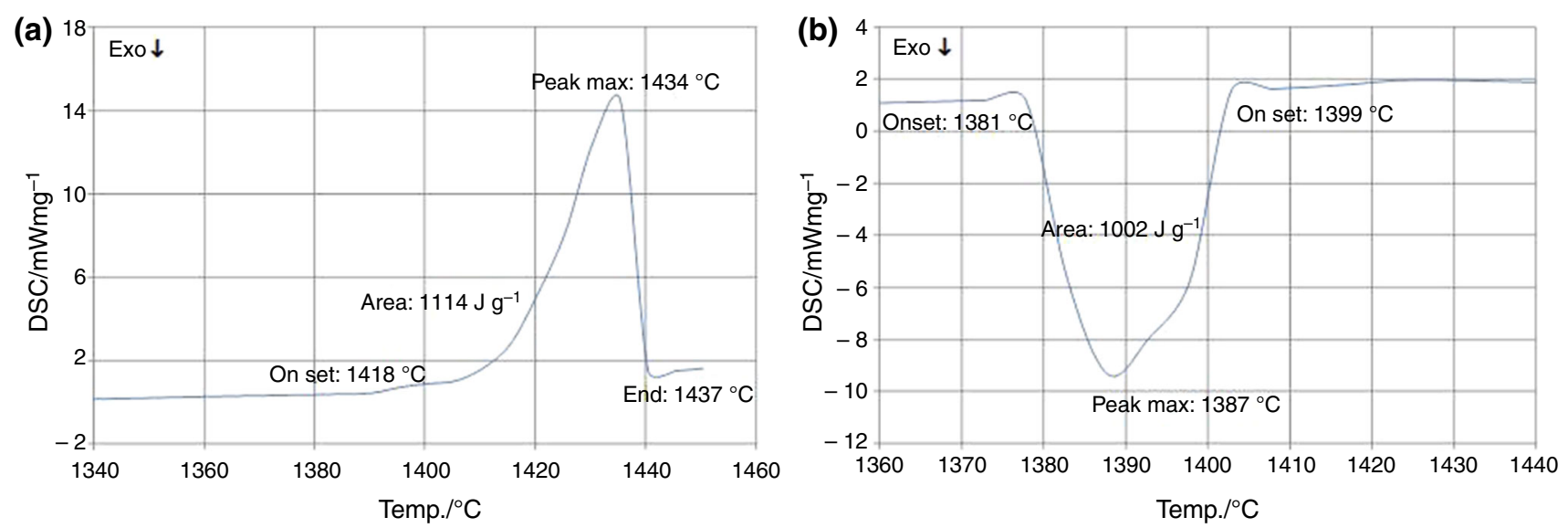

Fig. 1 The DSC curves recorded during continuous heating up to $T=1450{ }^{\circ} \mathrm{C}$ (a) and subsequent cooling up to $T=1360{ }^{\circ} \mathrm{C}(\mathbf{b})$ in h-BN crucible (Test \#1)
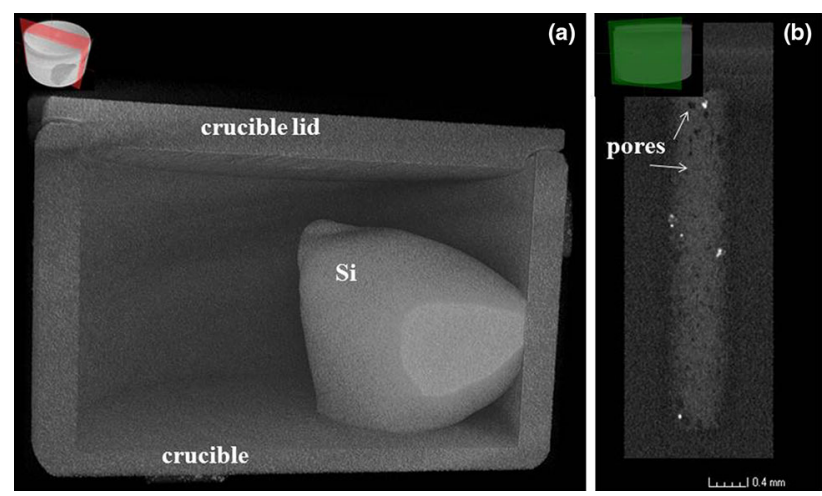

Fig. 2 Representative CT images after DSC test: a Si sample inside h-BN crucible, b part of h-BN crucible wall with visible pores and precipitates (inserts in the top of images correspond to $X Z$ plane)
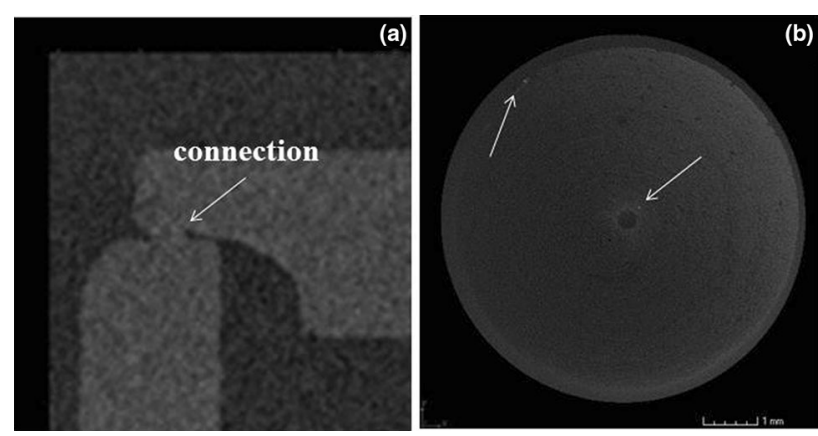

Fig. 3 The CT images of crucible lid: a connection between h-BN crucible and lid, b lid with light precipitates

this mass loss was caused from an evaporation of Si followed by its partial condensation at the crucible walls. This finding was documented by the presence of bright particles on the crucible walls and lid. Additionally, some parts of evaporated $\mathrm{Si}$ were removed from the crucible through the hole in the lid. In the next step, one single fragment of the crucible was subjected to detailed SEM examinations (Fig. 4) that also confirmed the CT observations, i.e., the porosity is formed in the crucible walls during DSC test.

Degradation of the h-BN crucible may follow the same route as the thermal decomposition of $\mathrm{h}$ - $\mathrm{BN}$ composite $\left(\mathrm{BN}+\mathrm{B}_{2} \mathrm{O}_{3}\right)$ described by Eichler and Lesniak [18] who described thermogravimetric measurements performed in a Netzsch STA 429 thermobalance under different atmospheres (Ar, vacuum, air and nitrogen) in the temperature range from 25 to $1600{ }^{\circ} \mathrm{C}$. They discovered that in both vacuum and air atmosphere at a temperature of about $1100{ }^{\circ} \mathrm{C}$, the mass of $\mathrm{h}-\mathrm{BN}$ changes and it grows in the air and decreases in a vacuum. The mass increase in the air atmosphere is most probably associated with the oxidation of $\mathrm{h}-\mathrm{BN}$ and the formation of boron oxide, whereas the decrease in mass in a vacuum is most probably related with the decomposition of h-BN. Hildenbrand and Hall [19] described decomposition process of $\mathrm{h}-\mathrm{BN}$ recorded by effusion method at temperature range of $1577-1887^{\circ} \mathrm{C}$. This process according to the reaction (1), where $\mathrm{N}_{2}$ is the only significant gaseous species in the temperature range, is investigated as:

$\mathrm{BN}(\mathrm{s})=\mathrm{B}(\mathrm{s})+\mathrm{N}_{2}(\mathrm{~g})$

J. Eichler and Ch. Lesniak [17] observed that thee mass decrease under the $\mathrm{Ar}$ atmosphere starts at a temperature of about $1420{ }^{\circ} \mathrm{C}$, while in nitrogen, it takes place at a temperature of about $1500{ }^{\circ} \mathrm{C}$.

Thus whatever the reason is (oxidation or decomposition of h-BN, Si evaporation), a change in the mass of the crucible and Si sample during DSC tests increases the error in the measurements of both latent heat of fusion and latent heat of crystallization. 


\section{DSC test in alumina crucible coated with h-BN spray (Test \#2)}

Taking into account the possible decomposition of the h-BN crucibles during DSC measurements, the next DSC test was performed in the $\mathrm{Al}_{2} \mathrm{O}_{3}$ crucibles that show high stability in the temperature range of our interest. However, in view of the recommendations by the producer [16], the $\mathrm{Al}_{2} \mathrm{O}_{3}$ crucibles should not be used at high temperatures for testing $\mathrm{Si}$ due to possible chemical reactions of liquid $\mathrm{Si}$ with $\mathrm{Al}_{2} \mathrm{O}_{3}$. In order to limit the reactivity between liquid $\mathrm{Si}$ and the $\mathrm{Al}_{2} \mathrm{O}_{3}$ crucible, its surface was covered with h-BN coating by using a commercial Henze HeBoCoat ${ }^{\circledR}$ 401E spray. The choice of this coating was based on the findings from own study [15] dedicated to the investigation of the effect of Henze HeBoCoat ${ }^{\circledR} 401 \mathrm{E}$ spray deposited on the $\mathrm{SiC}$ substrate on suppression of its reactivity with liquid $\mathrm{Si}$ at temperatures close to the melting point of $\mathrm{Si}$.

The procedure for coating the $\mathrm{Al}_{2} \mathrm{O}_{3}$ crucibles (sample crucible + reference crucible) with the h-BN coating involved three stages: (1) ultrasonic cleaning of crucibles with acetone for $5 \mathrm{~min}$ at $25{ }^{\circ} \mathrm{C}$ and then drying in a stream of warm air; (2) sputtering on internal surfaces of crucibles, h-BN spray; (3) heating crucibles in a thermal microbalance Netzsch STA 449 F3 Jupiter ${ }^{\circledR}$ device for $30 \mathrm{~min}$ under an $\mathrm{Ar}$ atmosphere at $800{ }^{\circ} \mathrm{C}$. The sensitivity and temperature calibrations were made with five pure metals (In, $\mathrm{Zn}, \mathrm{Bi}, \mathrm{Al}, \mathrm{Au}$ and $\mathrm{Ni}$ ) using h- $\mathrm{BN}^{\text {coating }} / \mathrm{Al}_{2} \mathrm{O}_{3}$ crucibles and the same other conditions as those applied for investigation of pure $\mathrm{Si}$ (flowing Ar; heating/cooling rate of $10 \mathrm{~K} \mathrm{~min}^{-1}$ ).

For the first DSC test (Test \#2.1), only internal surfaces of crucibles were covered by h-BN coating. The crucible lids were uncoated. The weighed (39.49 $\mathrm{mg}$ ) and degreased sample of Si was placed in a sample crucible. During DSC measurement in cooling segment, the abnormal run of DSC curve was observed and measurement was stopped. The run of heating DSC curve is shown in Fig. 5. During

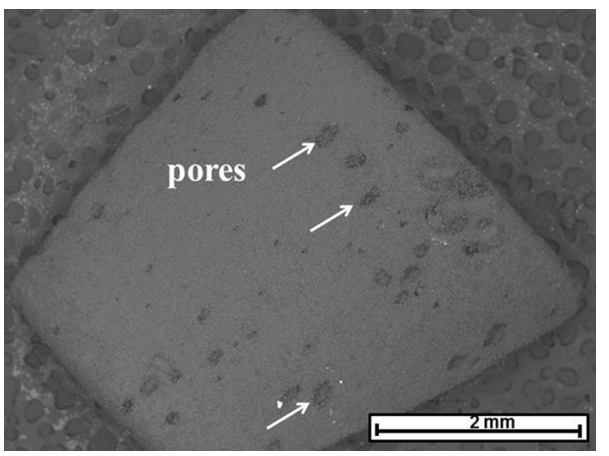

Fig. 4 SEM image of h-BN crucible wall fragment (top view)

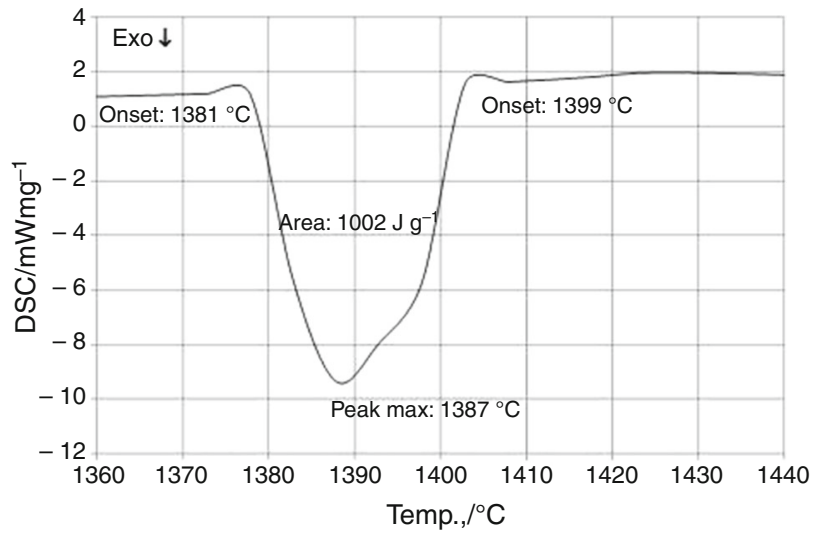

Fig. 5 The DSC curve recorded during continuous heating up to $T=1450{ }^{\circ} \mathrm{C}$ in h-BN ${ }^{\text {coating }} / \mathrm{Al}_{2} \mathrm{O}_{3}$ crucible (Test \#2.1)

heating, one endothermic peak was recorded. After reaching temperature of $1402{ }^{\circ} \mathrm{C}$, the Si sample melts (corresponding latent heat of fusion measured was $409.5 \mathrm{~J} \mathrm{~g}^{-1}$ ) and peak reaches a maximum at $1434{ }^{\circ} \mathrm{C}$.

At the end of the test, the crucible with the sample was opened and it was found that the $\mathrm{Si}$ sample changed its position and it was connected with the lid of the crucible (Fig. 6a). Visual observations showed that the solidified Si sample had the shape of a drop from which a cone protruded. The presence of the cone was associated with a change in the volume of the Si sample during solidification as it was also observed in [19]. Therefore, it can be assumed that the phenomenon of the cone formation during solidification caused the change in the Si sample position due to: (1) too large mass of the sample because the growing cone was so high thus it touched the uncoated $\mathrm{Al}_{2} \mathrm{O}_{3}$ lid; (2) easy transfer of the Si drop to the surface of the lid due to liquid Si wets well alumina [20]. To determine the mass of the Si sample after the test, an attempt was made to detach the drop from the lid. However, the drop could not be separated; therefore, nondestructive analysis by computed tomography using 3D-imaging of the

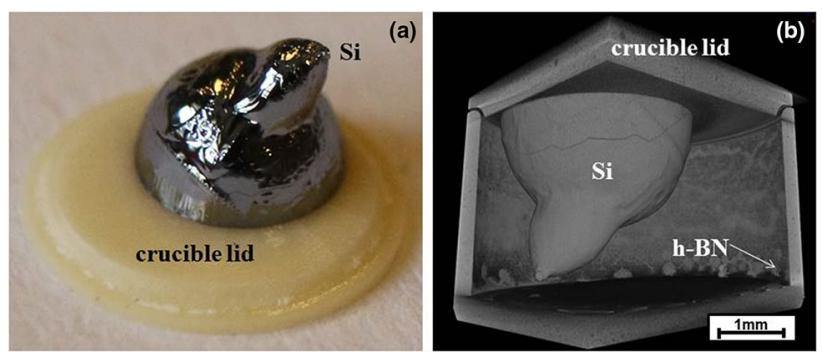

Fig. 6 Views of Si sample after DSC test: a photograph of solidified $\mathrm{Si}$ sample connected with alumina lid (upside down position of the lid), b 3D-CT image of alumina crucible coated with h-BN spray and covered with uncoated alumina lid showing Si drop solidified on the lid 

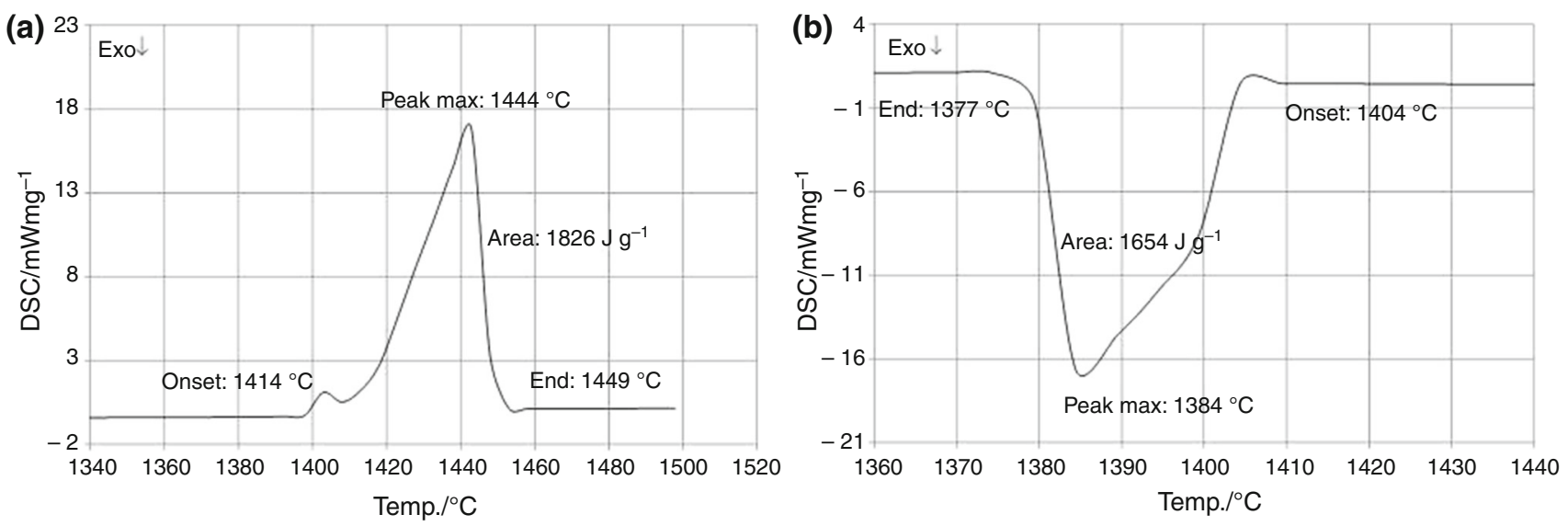

Fig. 7 The DSC curves recorded during heating up to $T=1450{ }^{\circ} \mathrm{C}$ (a) and cooling up to $T=1360{ }^{\circ} \mathrm{C}$ in h- $\mathrm{BN}^{\text {coating }} / \mathrm{Al}_{2} \mathrm{O}_{3}$ crucible (b) (Test \#2.2)

Table 1 The most important quantitative parameters extracted from the DSC heating and cooling curves

\begin{tabular}{|c|c|c|c|c|c|}
\hline \multicolumn{3}{|c|}{ Heating $/{ }^{\circ} \mathrm{C}$} & \multicolumn{3}{|c|}{ Cooling $/{ }^{\circ} \mathrm{C}$} \\
\hline$T_{\text {onset }}$ & $T_{\max }$ & $T_{\text {end }}$ & $T_{\text {onset }}$ & $T_{\max }$ & $T_{\text {end }}$ \\
\hline \multicolumn{6}{|c|}{ Test \#1with h-BN crucible } \\
\hline 1418 & 1434 & 1373 & 1399 & 1386 & 1381 \\
\hline \multicolumn{6}{|c|}{ Test \#2.1 with h-BN coating $/ \mathrm{Al}_{2} \mathrm{O}_{3}$ crucible } \\
\hline 1402 & 1434 & 1438 & - & - & - \\
\hline \multicolumn{6}{|c|}{ Test \#2.2 with $h$-BN coating $/ \mathrm{Al}_{2} \mathrm{O}_{3}$ crucible } \\
\hline 1414 & 1444 & 1449 & 1404 & 1384 & 1377 \\
\hline
\end{tabular}

Table 2 The values of the melting point, latent heat of fusion and solidification compared with the literature data [4-13]

\begin{tabular}{|c|c|c|c|c|c|}
\hline Method & Crucible & $\begin{array}{l}\text { Melting point/ } \\
{ }^{\circ} \mathrm{C}\end{array}$ & $\begin{array}{l}\text { Latent heat of fusion/ } \\
\mathrm{J} \mathrm{g}^{-1}\end{array}$ & $\begin{array}{l}\text { Latent heat of solidification/ } \\
\mathrm{J} \mathrm{g}^{-1}\end{array}$ & Refs. \\
\hline $\begin{array}{l}\text { Drop } \\
\text { calorimetry }\end{array}$ & h-BN sealed capsule & 1414 & 1720 & - & \multirow[t]{3}{*}{ [4] } \\
\hline $\mathrm{n} / \mathrm{a}$ & $\mathrm{n} / \mathrm{a}$ & 1414 & - & - & \\
\hline $\mathrm{n} / \mathrm{a}$ & $\mathrm{n} / \mathrm{a}$ & 1412 & - & - & \\
\hline $\mathrm{n} / \mathrm{a}$ & $\mathrm{n} / \mathrm{a}$ & 1414 & 1790 & - & {$[5,6]$} \\
\hline $\mathrm{n} / \mathrm{a}$ & $\mathrm{n} / \mathrm{a}$ & 1414 & 1790 & - & [7] \\
\hline $\mathrm{n} / \mathrm{a}$ & $\mathrm{n} / \mathrm{a}$ & 1410 & 1650 & - & [8] \\
\hline $\mathrm{n} / \mathrm{a}$ & $\mathrm{n} / \mathrm{a}$ & 1414 & 1790 & - & [9] \\
\hline $\mathrm{n} / \mathrm{a}$ & $\mathrm{n} / \mathrm{a}$ & 1412 & 1790 & - & {$[10]$} \\
\hline $\mathrm{n} / \mathrm{a}$ & $\mathrm{n} / \mathrm{a}$ & 1410 & 1800 & - & [11] \\
\hline $\mathrm{n} / \mathrm{a}$ & $\mathrm{n} / \mathrm{a}$ & - & 1790 & - & {$[12]$} \\
\hline $\mathrm{n} / \mathrm{a}$ & $\mathrm{n} / \mathrm{a}$ & 1423 & 1800 & - & [13] \\
\hline DSC & Commercial h-BN crucible & $1409^{\mathrm{a}}$ & $1114^{\mathrm{c}}$ & $1002^{c}$ & \multirow{2}{*}{$\begin{array}{l}\text { This } \\
\text { work }\end{array}$} \\
\hline DSC & $\begin{array}{l}\text { Commercial alumina } \\
\text { crucible }^{\mathrm{b}, \mathrm{d}}\end{array}$ & $1409^{a}$ & 1826 & 1654 & \\
\hline
\end{tabular}

${ }^{a}$ Melting point calculated as the average peak onset recorded during heating and cooling

${ }^{\mathrm{b}}$ Crucible covered with h-BN coating

${ }^{\mathrm{c}}$ The values underestimated due to different values of thermal conductivity of crucible

${ }^{\mathrm{d}}$ Test \#2 
whole crucible was performed (Fig. 6b) in order to determine the volume of Si sample after DSC test. The volume of $\mathrm{Si}$ was amounted to $15.9 \mathrm{~mm}^{3}$ that corresponds to the mass of $37.04 \mathrm{mg}$ calculated taking into account the density of $\mathrm{Si}\left(2.32983 \mathrm{~g} \mathrm{~cm}^{-3}\right)$. Thus, in this DSC test, the mass change of Si sample $(2.45 \mathrm{mg}) \Delta m$ was $6.2 \%$.

In order to avoid possible transfer of the molten $\mathrm{Si}$ sample to the lid, for the next DSC test (Test \#2.2), both the alumina crucible and the alumina lid were covered with an h-BN spray while the mass of the Si sample was decreased up to $30.43 \mathrm{mg}$. The run of DSC curves in the temperature range including melting and solidification of $\mathrm{Si}$ is shown in Fig. 7. On the DSC curve plotted during Si heating, one endothermic effect is observed (Fig. 7a). After reaching the temperature of $1414{ }^{\circ} \mathrm{C}$, the $\mathrm{Si}$ sample melts with corresponding heat of fusion $=1826 \mathrm{~J} \mathrm{~g}^{-1}$ and its maximum peak at $1434{ }^{\circ} \mathrm{C}$. During cooling, one exothermic peak is visible on the DSC curve (Fig. 7b). The Si sample starts solidification at $1404{ }^{\circ} \mathrm{C}$ and its maximum peak at $1384{ }^{\circ} \mathrm{C}$. The end of solidification is at $1377{ }^{\circ} \mathrm{C}$ with corresponding latent heat of solidification $=1654 \mathrm{~J} \mathrm{~g}^{-1}$.

Contrary to the previous measurement, after Test \#2.2 there was no any joint between the crucible and its lid. The crucible was opened, and the solidified $\mathrm{Si}$ sample was easily taken off the crucible due to a lack of bonding between them. The $\mathrm{Si}$ sample was then weighed on an analytical balance, and a mass loss of $\Delta m=5.2 \%$ was found. The most important quantitative parameters of the DSC curves are shown in Figs. 1a, b, 5 and $7 \mathrm{a}, \mathrm{b}$, and calculated temperatures are listed in Table 1.

The values collected in Table 1 show that the melting point of pure $\mathrm{Si}$ determined in the h- $\mathrm{BN}^{\text {coating }} / \mathrm{Al}_{2} \mathrm{O}_{3}$ crucible is $1414{ }^{\circ} \mathrm{C}$ (Test \#2.2) and $1402{ }^{\circ} \mathrm{C}$ (Test \#2.1), whereas in the $\mathrm{h}$-BN crucible, the melting point of $\mathrm{Si}$ is $1418{ }^{\circ} \mathrm{C}$ (Test \#1). Differences in detected temperatures probably are due to dissimilar thermal conductivity of alumina and h-BN at the test temperature, i.e., alumina $>10 \mathrm{~W} \mathrm{~m}^{-1} \mathrm{~K}^{-1} \quad$ (own studies); h-BN $\left(25 \mathrm{~W} \mathrm{~m}^{-1} \mathrm{~K}^{-1}\right)$ [21]. In the case of measurements carried out in the h-BN crucibles, such a calibration (using $\mathrm{Al}_{2} \mathrm{O}_{3}$ crucibles) could additionally underestimate the heat values measured. In the case of Test \#2.1, due to the change position of the sample the values for cooling process cannot be determined. The values of the melting point, latent heat of fusion and latent heat of solidification are collected in Table 2 and compared with previous studies using different methods [4-13].

Based on the literature data collected in Table 2, one may conclude that the melting point of pure $\mathrm{Si}$ is in the range of $1410-1423{ }^{\circ} \mathrm{C}$ [4-13] whereas the value of latent heat of fusion is between 1650 and $1800 \mathrm{~J} \mathrm{~g}^{-1}$. The values of melting point obtained experimentally in this work, both in the h-BN crucible $\left(1409{ }^{\circ} \mathrm{C}\right)$ and in the $\mathrm{Al}_{2} \mathrm{O}_{3}$ crucible $\left(1409{ }^{\circ} \mathrm{C}\right)$, are consistent with the available literature. However, the latent heat of fusion recorded in this study differs by $712 \mathrm{~J} \mathrm{~g}^{-1}$ and in the case of the h-BN crucible, it is significantly lower than the values given in the literature.

Although in the reviewed literature (Table 2) there is no data on latent heat of solidification, the compatibility of the remaining experimental results (melting point and latent heat of fusion) recorded in the $\mathrm{h}-\mathrm{BN}^{\text {coating }} / \mathrm{Al}_{2} \mathrm{O}_{3}$ crucible allows accepting the latent heat value of solidification obtained for this crucible as a reliable and reference value. The difference of $172 \mathrm{~J} \mathrm{~g}^{-1}$ between the latent heat of fusion and latent heat of crystallization values recorded in the same DSC test may be due to the change in sample mass.

In the case of using the h-BN crucible, the values of both latent heat of fusion and latent heat of solidification are significantly lower than those obtained in the h-BN ${ }^{\text {coating/ }}$ $\mathrm{Al}_{2} \mathrm{O}_{3}$ crucible, and despite a good agreement of the melting point value with the literature data, these values should not be considered reliable and used as a reference.

\section{Conclusions}

Based on the tests performed, it can be concluded that the differential scanning calorimetry with flow measurement enables experimental determination of the melting and solidification temperature of pure silicon coupled with measurement of the heat absorbed or released in the melting and solidification process. Due to compliance with the literature data, the obtained experimental values of melting temperature and the latent heat of fusion may serve as reference data. Despite the lack of the literature data on the value of the latent heat of solidification but taking into account a good agreement between the values of thermophysical properties measured in this study and those given the literature, we suggest that the heat of solidification obtained in this research can be used as a reference value.

Acknowledgements The project AMADEUS has received funds from the European Union's Horizon2020 research and innovation program, FET-OPEN action, under Grant agreement 737054. The sole responsibility for the content of this publication lies with the authors. It does not necessarily reflect the opinion of the European Union. Neither the REA nor the European Commission is responsible for any use that may be made of the information contained therein. The authors thank also Ms. Izabela Krzak for CT structural characterization.

Open Access This article is distributed under the terms of the Creative Commons Attribution 4.0 International License (http://creative commons.org/licenses/by/4.0/), which permits unrestricted use, distribution, and reproduction in any medium, provided you give appropriate credit to the original author(s) and the source, provide a link to the Creative Commons license, and indicate if changes were made. 


\section{References}

1. Reddya KS, Mudgala V, Mallick TK. Review of latent heat thermal energy storage for improved material stability and effective load management. J Energy Storage. 2018;15:205-27.

2. Farid MM, Khudhair AM, Razack SAK, Hallaj SA. A review on phase change energy storage: materials and applications. Energy Convers Manag. 2014;45(9-10):1597-615.

3. Datas A, Ramos A, Martí A, del Canizo C, Luque A. Ultra high temperature latent heat energy storage and thermophotovoltaic energy conversion. Energy. 2016;107:542-9.

4. Yamaguchi K, Itagaki K. Measurement of high temperature heat content of silicon by drop calorimetry. J Therm Anal Calorim. 2002;69:1059-66.

5. Belov GV, Iorish VS, Yungman VS. IVTANTHERMO-database on thermodynamic properties and related software. Calphad. 1999;23(2):173-80.

6. Knacke O, Kubaschewski O, Hesselman K. Thermochemical properties of inorganic substances. 2nd ed. Berlin: Springer; 1991. p. 1114-2412.

7. Dinsalde AT. SGTE data for pure elements. Calphad. 1991;15(4):317-425.

8. http://www.goodfellow.com/E/Silicon.html.

9. http://periodictable.com/Properties/A/FusionHeat.an.html.

10. Iida T, Guthrie RIL. The thermophysical properties of metallic liquids. Oxford: Oxford University Press; 2015. p. 506.

11. https://www.nuclear-power.net/silicon-specific-heat-latent-heatvaporization-fusion/.

12. Lida T, Guthrie RIL. The physical properties of liquid metals. Oxford: Clarendon Press; 1988.

13. Netzsch data: handbook of chemistry and physics, 76th edition, 1995-1996. D’ANS LAX Lehrbuh der Anorganishen Chemie,
Holleman \& Wiberg, de Gruyter Verlag; 1985. https://d2brmtk65 c6tyc.cloudfront.net/media/thermal-analysis/posters/ETZSCH_ Poster_TPoE_mitLUPE.pdf?

14. https://www.lesker.com/newweb/deposition_materials/materi aldepositionchart.cfm?pgid $=0$.

15. Polkowski W, Sobczak N, Nowak R, Kudyba A, Bruzda G, Polkowska A, Homa M, Turalska P. Effect of h-BN spray coatings on wetting and reactivity in $\mathrm{Si} / \mathrm{SiC}$ system. In: 1st international conference on metals, ceramics and composites (ICMCC'2017), Varna, Bulgaria, 14-16 September 2017, https://doi.org/10.5281/zendo.1098423.

16. Accessories for differential scanning calorimeters and thermobalances: crucibles, sensors, sample carriers, calibration kits for DSC, TGA and STA system. https://www.cif.iastate.edu/sites/ default/files/uploads/Other_Inst/TGA/Accessories $\% 20$ for $\%$ 20DSC \%2C\%20TGA\%2C\%20STA.pdf.

17. Krzak I, Tchórz A. The use of X-ray computed tomography as a tool in assisting cast material testing. Trans Foundry Res Inst. 2015;LV(3):33-42.

18. Eichler J, Lesniak C. Boron nitride (BN) and BN composites for high-temperature applications. J Eur Ceram Soc. 2008;28:1105-9.

19. Hildenbrand DL, Hall WF. The vaporization behavior of boron nitride and aluminum nitride. J Phys Chem. 1963;67(4):888-93.

20. Li JJ. Wetting of ceramic materials by liquid silicon, aluminium and metallic melts containing titanium and other reactive elements: a review. Ceram Int. 1994;20(6):391-412.

21. http://www.ioffe.ru/SVA/NSM/Semicond/BN/thermal.html.

Publisher's Note Springer Nature remains neutral with regard to jurisdictional claims in published maps and institutional affiliations. 